\title{
PENGGUNAAN MEDIA GAMBAR UNTUK MENINGKATKAN KEMAMPUAN MENULIS PARAGRAF SEDERHANA PADA MATA PELAJARAN BAHASA INDONESIA DI SEKOLAH DASAR
}

\author{
Sri Rezki Maulina Azmi \\ Sekolah Tinggi Manajemen Informatika dan Komputer (STMIK ROYAL) Kisaran \\ Jalan Prof. H.M. Yamin No. 173 Kisaran Kab. Asahan \\ srirezki.maulina@yahoo.com
}

\begin{abstract}
ABSTRAK
Peningkatan hasil belajar menulis paragraf sederhana pada pembelajaran bahasa indonesia dengan media gambar di sekolah dasar. Masalah umum dalam penelitian ini adalah bagaimana peningkatan pembelajaran menulis paragraf sederhana pada pembelajaran Bahasa Indonesia dengan bantuan media gambar di kelas III Sekolah Dasar Negeri 010145 Labuhan Ruku'. Penelitian ini merupakan penelitian tindakan kelas yang dilaksanakan dalam tiga siklus, masing-masing siklus mencakup tahap perencanaan, pelaksanaan, observasi, dan refleksi. Sumber datanya adalah siswa, teman sejawat, dokumen dan peneliti. Pengumpulan data dengan observasi, tes dan wawancara. Analisis penelitian berupa analisis deskriptif kualitatif dan analisis deskriptif kuantitatif. Hasilnya menunjukkan bahwa: penerapan media gambar dapat meningkatkan keterampilan menulis dengan enem langkah yaitu: (1) Interaksi, (2) Tanya jawab, (3) Penjelasan materi, (4) Menulis cerita atau deskripsi berdasarkan media gambar, (5) Membaca hasil tulisan, (6) Refleksi.
\end{abstract}

Kata Kunci: Media Gambar, Kemampuan Menulis

\begin{abstract}
Improved Learning outcomes to write a simple essay on learning Indonesia with a media images in Elementary School. A common problem in this research is the improvement of learning Indonesian with the help of the media images in third grade primary school 010145 Labhuhan Ruku? This research is classroom action research was conducted in three cycles, each cycle includes the planning, implementation, observation and reflection. Data source is the students, peers, documents, and researcher. Collecting data throught observation, test and interviews. Analysis of the research is a descriptive analysis kualitatif and descriptive analysis kuantitatif. The results show that : the application of media images can improve writing skills with six steps: (1) interaction, (2) question and answers, (3) A description of the material, (4) write a story or a description based on media image, (5) Reading the writings and (6) reflection.
\end{abstract}

Keywords: Media Picture, Writing Skills

\section{PENDAHULUAN}

\section{A. Latar Belakang}

Semua kegiatan dalam masyarakat tidak terlepas dari bahasa. Semua orang menyadari bahwa interaksi sesama manusia memerlukan bahasa untuk berkomunikasi. Dengan bahasa, manusia dapat berekspresi, menyampaikan pesan, ide, gagasan, atau pendapat. Tidak berlebihan apabila kita mengatakan bahwa bagian dari kehidupan. Dalam kehidupan berbahasa kita mengenal empat kemampuan berbahasa, yakni : menyimak, berbicara, membaca, dan menulis. Keempat keterampilan tersebut merupakan satu kesatuan yang saling menunjang. Dalam hal ini seorang ahli mengemukakan : "Setiap keterampilan itu erat sekali hubungannya dengan ketiga keterampilan lainnya dengan cara yang beraneka ragam. Dalam memperoleh keterampilan berbahasa biasanya kita melalui hubungan urutan teratur mula-mula pada 
waktu kecil kita belajar menyimak bahasa, kemudian berbicara, sesudah itu kita belajar membaca dan menulis. Menyimak dan berbicara kita pelajari sebelum masuk sekolah. Keempat keterampilan itu pada dasarnya merupakan satu kesatuan, merupakan catur tunggal" (Tarigan $1985: 1$ ).

Setiap keterampilan berbahasa erat pula hubungannya dengan proses-proses yang mendasari bahasa. Bahasa mencerminkan pikiran seseorang. Semakin terampil berbahasa akan semakin cerah dan jelas jalan pikirannya. Untuk memperoleh keterampilan itu, kita perlu memperbanyak latihan, karena hanya melalui latihan, keterampilan itu dapat dimiliki. Melatih keterampilan berbahasa sama dengan melatih keterampilan berfikir.

Dalam memperoleh keterampilan berbahasa, kita biasanya melalui suatu hubungan tahapan yang teratur pada masa pra sekolah biasanya anak sudah mulai belajar menyimak dan berbicara, sesudah memasuki usia sekolah barulah anak belajar membaca dan menulis (Tarigan 1981 : 1). Bahasa tulis memiliki kelebihan terutama untuk hal-hal yang bersifat ilmiah. Pembuatan makalah, skripsi, dan karya ilmiah lainnya tidak akan terlepas dari penggunaan bahasa tulis. Untuk itu, keterampilan menulis sering dijadikan objek penelitian. Hal ini tidak berarti mengabaikan keterampilan berbahasa yang lainnya. Melalui tulisan dapat diperoleh gambaran keleluasaan wawasan dan kemampuan seseorang dalam disiplin ilmu tertentu, baik dalam bidang ilmu bahasa maupun ilmu lainnya.

Mengingat pentingnya keterampilan menulis dalam kehidupan masyarakat, maka tidak heran jika pakar-pakar bahasa melalui kurikulum yang mereka susun menggiring siswa agar menguasai bidang tersebut. Hal ini terlihat dalam rumusan tujuan pengajaran Bahasa Indonesia yang berhubungan dengan pengajaran menulis, yakni siswa memiliki kemampuan berbahasa Indonesia yang dapat digunakan untuk menulis. Tujuan ini dijabarkan untuk setiap jenjang pendidikan. Jelaslah bahwa dalam tujuan tersebut diharapkan siswa dapat menyampaikan ide atau pesan secara tertulis melalui tulisan.

Kemampuan keterampilan menulis untuk kelas III Sekolah Dasar, seperti tuntutan kurikulum; tidak hanya mereka terampil membuat kalimat yang runtut dan mudah dipahami tapi siswa kelas III SD juga dituntut dapat menyusun beberapa kalimat sehingga membentuk satu paragraf. Meskipun berbagai teori menulis diajarkan disetiap jenjang pendidikan, pada umumnya siswa belum mampu menulis dengan baik sesuai jenjang, terutama dalam menulis paragraf. Ini semua penulis temukan di lapangan ketika mengajar di kelas III SDN 010145 LABUHAN RUKU. Oleh karena itu, penulis tertarik untuk mengadakan penelitian, dimana dalam observasi awal menunjukkan keterampilan menulis paragraf sederhana di kelas III SDN 010145 LABUHAN RUKU masih sangat kurang dan belum memuaskan dengan rata-rata nilai dibawah nilai ketuntasan yang ditetapkan yaitu 65.

Dalam hal ini, peran guru sangat penting. Seorang guru bukan hanya harus menguasai materi ajar tetapi juga harus memilki dan menguasai teknik-teknik pembelajaran, sehingga pembelajaran dapat dilaksanakan sesuai dengan tujuan yang akan dicapai. Untuk menciptakan proses pembelajaran yang baik, seorang guru harus memperhatikan karakteristik anak dan berbagai teori belajar yang dikemukakan oleh para ahli, serta penggunaan alat peraga yang sesuai dengan materi ajar sehingga dapat tercipta proses pembelajaran yang tepat, efektif, dan efisien. Menurut Wijaya dan Rusyan (1994 : 37) "mediaberperan sebagai perangsang belajar dan dapat menumbuhkan motivasi belajar sehingga siswa tidak menjadi bosan dalam meraihtujuan-tujuan belajar".

Berdasarkan uraian diatas, penulis mencoba memperbaiki pembelajaran dengan menggunakan media gambar untuk meningkatkan kemampuan menulis paragraf sederhana di kelas III SDN010145 LABUHAN RUKU, Kabupaten Batu Bara.

\section{B. Rumusan Masalah}

Untuk lebih memfokuskan kajian studi ini, permasalahan penelitian yang akan diungkapkan melalui studi ini, maka permasalahan tersebut dijabarkan dengan pertanyaan penelitian diarahkan pada aspekaspek sebagai berikut :

1. Bagaimana aktivitas siswa dalam pembelajaran menulis paragraf sederhana melalui media gambar pada siswa kelas III SDN 010145 Labuhan Ruku'

2. Bagaimanakah hasil belajar siswa dalam menulis paragraf sederhana setelah menggunakan media gambar pada siswa kelas III SDN 010145 Labuhan Ruku’ 


\section{Hipotesis Tindakan}

Berdasarkan latar belakang masalah dan uji literatur yang telah ditemukan maka hipotesis yang diajukan dalam penelitian ini adalah Penggunaan Media Gambar Untuk Meningkatkan Kemampuan Menulis Paragraf Sederhana di Kelas III SDN , 010145 Labuhan Ruku Kabupaten Batu Bara.

\section{Tujuan dan Manfaat Penelitian}

\section{Tujuan Penelitian}

Sesuai dengan permasalahan dan fokus studi, peneliti merumuskan tujuan penelitian sebagai berikut :

1. Untuk mengetahui aktivitas pembelajaran menulis paragraf sederhana melalui media gambar pada siswa kelas III SDN 010145 Labuhan Ruku

2. Untuk mengetahui peningkatan hasil belajar siswa dalam menulis paragraf sederhana denganmenggunakan media gambar pada siswa kelas III SDN 010145 Labuhan Ruku.

\section{Manfaat Penelitian}

Adapun penelitian ini dapat memberikan manfaat secara :

1. Teoritis, untuk mengkaji ilmu pendidikan khususnya mengenai media pembelajaran efektif yang dapat digunakan dalam pembelajaran Bahasa Indonesia khususnya menulis paragraf yang dapatmeningkatkan mutu pendidikan.

2. Praktis, bermanfaat bagi :

\section{a. Guru}

Penelitian ini dapat memberikan informasi dan menambah wawasan serta sebagai bahan masukan guru dalam mata pelajaran Bahasa Indonesia pada pembelajaran menulis paragraf sederhana dapat menggunakan media gambar.

\section{b. Sekolah}

Dengan hasil penelitian ini diharapkan SDN X, Kabupaten X dapat lebih meningkatkan pemberdayaan alat peraga yang menarik agar prestasi belajar siswa lebih baik dan perlu dicoba untuk diterapkan pada pembelajaran Bahasa Indonesia dan pelajaran lain.

\section{c. Siswa}

Penelitian ini dapat memberikan kesempatan kepada siswa untuk menggali pengetahuan, meningkatkan kreatifitas serta melatih keterampilan menulis paragraf dengan menggunakan alat peraga berupa gambar.

\section{E. Penjelasan Istilah}

Agar mudah memahami istilah yang digunakan serta tidak menimbulkan pemahaman yang berbeda. Penulis akan menjelaskan istilah yang digunakan sebagai berikut :

1. Media gambar adalah media yang mengkombinasikan pengungkapan kata-kata dengan gambar-gambar.

2. Meningkatkan adalah proses upaya-upaya kegiatan yang dilakukan supaya terjadi suatu perubahan ke arah yang lebih baik dan atau bertambahnya sesuatu perubahan dari segi jumlah/kuantitas.

3. Menulis dalam penelitian ini adalah menulis paragraf sederhana adalah proses belajar mengajar dengan materi pembelajaran berupa menulis paragraf sederhana.

4. Kemampuan menulis adalam keterampilan berbahasa yang dipergunakan untuk berkomunikasi secara tidak langsung, tidak secara tatap muka dengan orang lain.

5. Paragraf sederhana adalah deretan dua kalimat atau lebih yang memiliki satu ide pokok atau gagasan pokok, diikuti beberapa kalimat penjelas. 


\section{B. KAJIAN TEORI DAN PUSTAKA}

\section{Kajian Teori}

Tujuan utama pembelajaran Bahasa Indonesia adalah meningkatkan keterampilan siswa dalam Bahasa Indonesia, pengetahuan bahasa diajarkan untuk menunjukan siswa terampil berbahasa yakni terampil menyimak, berbicara, membaca dan menulis. Keterampilan berbahasa hanya bisa dikuasai dengan latihan yang terus menerus dan sistematis yakni harus sering berlatih menyimak, berbicara, membaca, dan menulis. Mata pelajaran Bahasa Indonesia adalah program untuk mengembangkan pengetahuan, keterampilan berbahasa, dan sikap positif terhadap bahasa.

\section{Pengertian Menulis}

Menulis adalah menyampaikan ide atau gagasan dan pesan dengan menggunakan lambang grafik (tulisan). Tulisan adalah suatu system komunikasi manusia yang menggunakan tanda-tanda yang dapat dibaca atau dilihat dengan nyata. Tarigan (dalam Agus Suriamiaharja, $1996: 1$ ) berpendapat bahwa "Menulis adalah menurunkan atau melukiskan lambang-lambang grafik yang menggambarkan suatu bahasa yang dipakai oleh seseorang, sehinga orang lain dapat membaca lambang-lambang grafik tersebut kalau mereka memahami bahasa dan gambaran grafik tersebut ."

Robert Lodo (dalam Suriamiaharja, 1996 : 1), mengatakan bahwa "Menulis adalah menempatkan simbol - simbol grafik yang menggambarkan suatu bahasa yang dimengerti oleh seseorang, kemudian dapat dibaca oleh orang lain yang memahami bahasa tersebut beserta simbolsimbol grafiknya".

Dari uraian di atas dapat disimpulkan bahwa menulis adalah kemampuan seseorang dalam melukiskan lambang - lambang grafik untuk menyampaikan ide atau gagasan yang dapat dimengerti oleh orang lain.

\section{Pengertian Mengarang}

Apabila seseorang menggunakan buah pikiran, gagasan, perasaan, pengalaman atau lainya kedalam bahasa tulis, kegiatan tersebut adalah kegiatan mengarang. Untuk dapat menyampaikan suatu pikiran, gagasan, perasaan, pengalaman atau lainya, seseorang perlu memiliki pembendaharaan kata yang memadai, terampil menyusun kata-kata menjadi kalimat yang jelas, dan mahir memakai bahasa secara efektif.

The Liang Gie ( 1992 : 18 ), mengungkapkan bahwa "Untuk dapat menyampaikan gagasan dan fakta secara lincah dan kuat, seseorang perlu memiliki pembendaharaan kata yang memadai, terampil menyusun kata-kata menjadi beraneka kalimat yang jelas, dan mahir memakai bahasa secara efektif". Menurut pengertianya, "mengarang adalah keseluruhan rangkaian kegiatan seseorang mengumpulkan gagasan dan menyampaikannya melalui bahasa tulis kepada pembaca untuk dipahami". ( The Liang Gie, $1992: 17$ ).

Dalam proses mengarang setiap ide perlu dilibatkan pada suatu kata, kata-kata dirangkai menjadi sebuah kalimat, kemudian kalimat-kalimat membentuk paragraf, dan paragraph-paragraf akhirnya mewujudkan sebuah karangan. Sedangkan karangan merupakan hasil dari kegiatan mengarang, yaitu perwujudan gagasan seseorang dalam bahasa tulis yang dapat dibaca dan dipahami oleh orang lain.

Beberapa buku ada pula yang mennyebutkan bahwa mengarang sebagai suatu penyampaian pikiran secara resmi dan teratur melalui ucapan maupun tulisan. Dari uraian tersebut diatas dapat disimpulkan bahwa mengarang adalah kegiatan menulis yang tersusun dengan teratur dari kata, kalimat, sampai paragraf yang saling berhubungan dan merupakan kesatuan yang utuh, dengan maksud menceritakan kejadiaan atau peristiwa, mempercakapkan sesuatu, dan tujuan lainya.

\section{Unsur Mengarang}

Berbicara mengenai karangan baik yang berupa karangan pendek maupun panjang, maka kita harus berbicara mengenai beberapa hal atau masalah disekitar karangan. The Liang Gie (1992 : 17) mengemukakan ada 4 (empat) unsur dalam mengarang yaitu sebagai berikut : 
a. Gagasan ( Idea ),

yaitu topik berikut tema yang diungkapkan secara tertulis.

b. Tuturan (Discourse )

yaitu bentuk pengungkapan gagasan sehingga dapat dipahami pembaca.

Ada 5 (lima) bentuk karangan :

1) Penceritaan / Narasi (Narration )

Bentuk pengungkapan yang menyampaikan sesuatu peristiwa / pengalaman .

2) Pelukisan / Deskripsi ( Description )

Bentuk pengungkapan yang menggambarkan pengindraan, perasaan mengarang

tentang mecam - macam hal yang berada dalam susunan ruang (misalnya pemandangan indah, lagu merdu, dll).

3) Pemaparan / Eksposisi ( Exposition )

Bentuk pengungkapan yang meyajikan secara fakta - fakta yang bermaksud memeberi penjelasan kepada pembaca mengenai suatu ide, persoalan, proses atau peralatan.

4) Perbincangan / Argumentasi (Argumentation )

Bentuk pengungkapan dengan maksud memberikan alasan dan bukti, untuk mempengaruhi pikiran pembaca demi memperkuat atau menolak suatu pendapat, pendirian, atau gagasan.

5) Ajakan / Persuasi (Persuation)

Bentuk pengungkapan yang berisi paparan yang berdaya-bujuk, ataupun daya-himbau untuk meyakini atau mengikuti himbauan yang dilontarkan oleh penulis.

c. Tatanan (Organization)

Yaitu tertib pengaturan dan peyusunan gagasan dengan mengindahkan berbagai asas, aturan, dan teknik sampai merencanakan rangka dan langkah .

d. Wahana (Meduim)

Yaitu sarana pengantar gagasan berupa bahasa tulis yang terutama menyangkut kosakata, gramatika (tata bahasa), dan terotika (seni memekai bahasa secara efektif ).

\section{Tujuan Pengajaran Mengarang}

Ngalim Purwanto, dan Djeniah Alim (1997 : 58) mengemukakan bahwa tujuan pengajaran mengarang sama dengan tujuan pengajaran bercakap- cakap hanya berbeda dengan bentuk tulisan, yaitu :

a. Memperkaya perbendaharaan bahasa positif dan aktif

b. Melatih melahirkan / mengungkapkan pikiran dan perasaan dengan tepat

c. Melatih memaparkan pengalaman - pengalaman dengan tepat.

d. Melatih penggunaan ejaan yang tepat (untuk menguasai bentuk bahasa).

\section{Macam-macam Karangan di SD}

Macam-macam karangan yang dapat diajarkan di SD dapat dijelaskan sebagai berikut:

a. Menurut Tingkatan

1. Karangan permulaan ( Kelas I dan II )

2. Karangan sebenarnya ( Karangan lanjutan ) di kelas- kelas berikutnya.

b. Menurut Isi / Bentuk

1. Karangan Varslag ( Laporan ), Umumnya diberikan di kelas - kelas rendah Misalnya : Menceritakan kembali ( secara tertulis ) apa - apa yang dialami dalam pengajaran lingkungan.

2. Karangan Fantasi, Mengeluarkan isi jiwa sendiri ( Ekspresi jiwa ), Misalnya : "Cita-citaku Setelah Tamat SD”, "Seandainya Aku Jadi Raja", dll.

3. Karangan Reproduksi, umumnya bersifat menceritakan / menguraikan suatu perkataan yang telah di pelajari atau di pahami, seperti mengenal ilmu- ilmu bumi, ilmu hayat, atau menulis dengan kata- kata sendiri apa yang telah di baca, dll.

4. Karangan Argumentasi, karangan berdasarkan alasan tertentu. Siswa dibiasakan menyatakan pendapat ataupun pikiranya berdasarkan alasan yang tepat. 


\section{c. Menurut Susunanya}

1. Karangan Terikat

2. Karangan Bebas

3. Karangan setengah bebes terikat(Ngalim Purwanto dan Djeinah Alim, 1997 : 59)

\section{Karangan Permulaan}

Pendapat lama mengatakan mengajar mengarang itu baru diberikan di kelas V sekolah rendah, karena syarat-syarat yang ditentukan untuk mengarang itu adalah berat, seperti ejaan bahasa, susunan kalimat, isi, tanda baca, dan sebagainya.

Sementara itu pendapat sekarang, mengarang itu semenjak di kelas I (satu) sudah mulai disisipkan (Mengarang Permulaan). Di kelas I (satu) sudah dapat di mulai dengan menggambar bebas kemudian anak menulis beberapa kalimat tentang gambarnya. Di kelas III (tiga) adalah lanjutan dari kegiatan di atas. Cerita tentang gambar telah memakai judul, kalimat lebih banyak pada saat menceritakan tentang benda, hewan atau tanaman yang sesuai dengan lingkungan, anak telah menjelaskan sesuatu tentang benda. Mulailah anak, menentukan pokok pikiran yang mungkin akan menjadi karangan. Hal ini lebih mudah dilatihkan melalui mengarang dengan bentuk gambar seri. (Ngalim Purwanto dan Djeinah Almim, 1997 : 59).

\section{Susunan Karangan}

Tarigan dan Sulistyaningsih (1996 : 362) mengemukakan "Wacana dibentuk oleh paragraph-paragraf, sedangkan paragraf dibentuk oleh kalimat-kalimat. Kalimat-kalimat yang membentuk paragraf itu haruslah merangkai, kalimat yang satu dengan kalimat berikutnya harus berkaitan begitu seterusnya. Sehingga membentuk satu kesatuan yang utuh atau membentuk sebuah gagasan. Selanjutnya paragraf dengan paragraf pun merangkai secara utuh membentuk sebuah wacana yang memiliki tema yang utuh."

\section{a. Kata}

Setiap gagasan pikiran atau perasaan dituliskan dalam kata-kata. Kata adalah unsur yang diucapkan atau dituliskan yang merupakan perwujudan kesatuan perasaan dan pikiran yang dapat di gunakan dalam bahasa. Untuk dapat menyampaikan gagasan, pikiran dan perasaan dalam tulisan karangan. Seorang perlu memiliki pembendaharaan kata yang memedai dan pemilihan kata yang tepat. "Dalam memilih kata itu harus diberikan dua persyaratan pokok yaitu (1) Ketepatan (2) Kesesuaian" (Suriamiharja et - al, 1996 : 25). Persyaratan ketepatan yaitu kata-kata yang dipilih harus secara tepat mengungkapkan apa yang ingin di ungkapkan sehingga pembaca juga dapat menafsirkan kata-kata tersebut tepat seperti maksud penulis. Persyaratankesesuaian menyangkut kecocokan antara kata-kata yang dipakai dengan kesempatan / situasi dengan keadaan pembaca. Pilihan kata dan gaya bahasa yang dipergunakantidak merubah suasana atau tidak menyinggung perasaan orang yang hadir.

\section{b. Kalimat}

Kalimat terbentuk dari gabungan anak kalimat, sedangkan anak kalimat adalah gabungan dari ungkapan atau frase, dan ungkapan itu sendiri merupakan rangkaian dari kata-kata .Kalimat yang dipergunakan dalam karangan berupa kalimat yang efektif yaitu kalimat yang benar dan jelas sehinga mudah dipahami orang lain. Sebuah kalimat efektif haruslah memiliki kemampuan untuk menimbulkan kembali gagasan pada pikiran pandangan atau pembaca seperti apa yang terdapat pada pikiran penulis atau pembaca. Suryamiharja et-al (1996 : 38), mengemukakan bahwa Kaliamat efektif dalam bahasa tulis, haruslah memiliki unsur- unsur :

1) Dapat mewakili gagasan penulis

2) Sanggup menciptakan gagasan yang sama tepatnya dalam pikiran pembaca seperti yang dipikirkan penulis.

Sedangkan Widdowson (1997) berpendapat bahwa kalimat efektif memiliki 2 dua) persyaratan, yaitu persyaratan kebenaran dan persyaratan kecocokan. Persyaratan kebenaran bertolok ukur kebenaran kaidah berbahasa. Persyaratan kecocokan bertolok ukur atas kecocokan atau kekompakan kalimat dalam konteks, baik konteks kebahasaan maupun konteks non-kebahasaan. 


\section{c. Paragraf}

Paragraf adalah satu kesatuan pikiran, suatu kesatuan yang lebih tinggi atau lebih luas dari pada kalimat : paragraf merupakan kimpulan kalimat yang berkaitan dalam suatu rangkaian untuk membentuk sebuah gagasan, Berkaitan dengan paragraf Akhadiah, dkk (dalam Agus Suryamiharja, 1996 : 46), menjelaskan bahwa "Dalam paragraph terkandung satu unit buah pikiran yang didukung oleh semua kalimat utama atau kalimat topik, kalimat penjelas sapai kalimat penutup".

Fungsi dari paragraf dalam karangan adalah :

1) Sebagai penampung dari sebagian kecil jalan pikiran atau ide keseluruhan karangan.

2) Memudahkan pemahaman jalan pikiran atau ide pokok karangan. (Tarigan, 1996)

Menurut Suriamuharja (1996 : 48) "Paragraf baik dan efektif harus memenuhi 3 (tiga) parsyaratan, yaitu Kohesi (Kesatuan ), Koherensi (Kepaduan), dan Pengembangan / Kelengkapan paragraf”.

\section{1) Kohesi (Kesatuan)}

Kesatuan paragraph akan terwujud jika 2 hal terpenuhi. Pertama, paragraf hanya mengandung sebuah kalimat topik yang berarti hanya berisi sebuah gagasan dasar. Kedua, paragraf berisi kalimat atau sejumlah kalimat pengembang yang berisi sebuah gagasan atau sejumlah gagasan pengembang. Gagasan pengembang itu merupakan penjelas atau atribut terhadap gagasan dasar.

Keraf (dalam Suriamiharja 1996 : 48) mengemukakan bahwa "yang dimaksud dengan kohesi / kesatuan dalam paragraf adalah semua kalimat yang membina paragraf secara bersama - sama menyatakan satu hal, satu tema tertentu".

\section{2) Koherensi (Kepaduan)}

Kepaduan berarti keserasian gagasan hubungan antargagasan dalam paragraf yang berarti juga keserasian hubungan antarkalimat dalam paragraf. Keserasian itu menyebabkan alur gagasan atau informasi yang terungkap dalam paragraph menjadi lancar.

Keraf (Suriamiharja 1996 : 48) mengemukakan bahwa "yang dimaksed dengan koherensi / keterpaduan dalam paragraf adalah kekompakan hubungan antar sebuah kalimat denngan kalimat yang lain yang membentuk paragraf itu".

\section{3) Pengembangan / Kelengkapan paragraf}

Keraf (dalam Suryamiharja 1966 : 50), mengemukakan bahwa "pengembangan paragraf adalah penyusunan atau perincian dari gagasan-gagasan yang membina peragraf itu",

Suatu paragraf dikatakan berkembang atau lengkap jika kalimat topik atau kalimat utama dikembangkan atau dijelaskan dengan cara menjabarkannya dalam bentuk-bentuk kongkrit, dapat dengan cara pemaparan dan pemberian contoh, penganalisaan dan nilai - nilai.

\section{Media Pembelajaran}

\section{a. Pengertian Media Pembelajaran}

Kata "Media" secara harpiah adalah "perantara atau pengantar". Pengertian media sebagai sumber belajar adalah "Manusia, benda, ataupun peristiwa yang memungkinkan anak didik memperoleh pengetahuan dan keterampilan" (Djamarah dan Zein, 1996 :136). Penggunaan media dalam proses belajar mengajar sangat penting. Ketidakjelasan guru dalam menyampaikan bahan pengajaran dapat terwakili dengan kehadiran media. Pada tingkatan SD siswanya belum mampu berfikir abstrak, masih berfikir kongrit. Keabstrakan bahan pelajaran dapat dikongritkan dengan kehadiran media, sehingga anak didik lebih mudah mencerna bahan pelajaran daripada tanpa bantuan media. Dalam penggunaan media, perlu diperhatikan bahwa pemilihan media pengajaran haruslah jelas dengan tujuan pengajaran yang telah dirumuskan., apabila diabadikan media pengajaran bukanya membantu proses belajar mengajar, tapi sebagai penghambat dalam pencapaian tujuan secara efektif dan efesien.

Dari uraian tersebut diatas dapat disimpulkan bahwa media adalah segala sesuatu yang dapat digunakan untuk menyalurkan pesan, membantu mempertegas bahan pelajaran, sehingaga dapat merangsang pikiran, perasaan, perhatian dan minat siswa dalam proses belajar. 


\section{b. Fungsi Peranan Media Pengajaran}

Fungsi media pengajaran sebagai sumber belajar, Nana Sudjana (dalam Djamarah, 1996 : 152), Merumuskan fungsi media sebagai berikut :

1) Penggunaan media dalam proses belajar mengajar bukan merupakan fungsi tambahan, tetapi mempunyai fungsi sendiri sebagai alat Bantu untuk mewujudkan situasi belajar mengajar yang efektif.

2) Penggunana media pengajaran merupakan bagian yang integral dari keseluruhan situasi mengajar.

3) Media pengajaran, penggunaannya dengan tujuan dari sisi pelajaran .

4) Penggunaan media bukan semata-mata alat hiburan, bukan sekedar melengkapi proses belajar supaya lebih menarik perhatian siswa.

5) Penggunaan media dalam pengajaran lebih dituangkan untuk mempercepat proses belajar mengajar dan membantu siswa dalam menangkap perhatian yang diberikan guru.

6) Pengunaan media dalam pengajaran diutamakan untuk mempertinggi mutu belajar mengajar.

Ketika fungsi-fungsi media pengajaran itu diaplikasikan ke dalam proses belajar mengajar , maka terlihatlah perannya sebagai berikut :

1) Media yang digunakan guru sebagai penjelas dari keterangan terhadap suatu bahan yang guru sampaikan.

2) Media dapat memunculkan permasalahan untuk dikaji lebih lanjut dan dipecahkan oleh para siswa dalam proses belajarnya.

3) Media sebagai sumber belajar bagi siswa.

\section{c. Kriteria Pemilihan Media Pengajaran}

Nana Sudjana dan Ahmad Rivai (dalam Djamarah dan Zein, 1996 : 150), mengemukakan beberapa kriteria dalam memilih media pelajaran, sebagai berikut:

1) Ketepatan dengan tujuan pengajaran.

2) Dukungan terhadap isi bahan pelajaran. Adanya media bahan pelajaran lebih mudah dipahami siswa.

3) Media yang digunakan mudah diperoleh, mirah, sederhan dan praktis penggunaannya.

4) Keterampilan guru dalam menggunakan media dalam proses pengajaran.

5) Tersedia waktu untuk menggunakanya, sehinga media tersebut dapat bermanfaat bagi siswa selama pengajaran berlangsung.

6) Sesuai dengan tarap berpikir siswa.

\section{d. Media Cerita Gambar Seri Sebagai Model Pembelajaran}

Dalam kriteria pemilihan media disinggung bahwa media digunakan harus sesuaidengan taraf berfikir anak didik. Demikian pula dalam pembelajaran menulis karangan di SD. Penggunaan media gambar seri dirasakan sangat tepat untuk membantu siswa dalam keterampilan mengarang. Dengan melihat gambar, siswa dapat menarik isi kesimpulan dari gambar tersebut, kemudian dapat menguraikan dalam bentuk tulisan. Berkaitan dengan penggunaan media gambar, Purwanto dan Alim (1997 : 63), mengemukakan bahwa "Penggunaan media gambar untuk melatih anak menentukan pokok pikiran yang mingkin akan menjadi karangan - karangan", juga Tarigan (1997 :210) mengemukakan bahwa "Mengarang melalui media gambar seri berarti melatih dan mempertajam daya imajinasi siswa".

Dari uraian di atas, dapat ditarik kesimpulan bahwa cerita gambar seri adalah cara atau daya upaya dalam menyusun atau menulis suatu tulisan atau karangan dengan menerjemahkan isi pesan visual (gambar seri) ke dalam bentuk tulisan.

\section{e. Ciri-ciri Gambar Yang Baik dan Peranannya Sebagai Media Pengajar}

Gambar yang baik dan dapat digunakan sebagai sumber belajar adalah yang memiliki ciri- ciri sebagaimana dikemukakan Sudirman et-al (1991 : 219), yaitu :

1) Dapat menyampaikan pesan atau ide tertentu.

2) Memberi kesan kuat dan menarik perhatian. 
3) Merangsang orang yana melihat untuk ingin mengungkapkan tentang obyek-obyek dalam gambar.

4) Berani dan dinamis.

5) Ilustrasi tidak terlalu banyak, tetapi menarik dan mudah dipahami.

Sedangkan peranan gambar sebagai media pengajaran yaitu :

1) Dapat membantu guru dalam menyampaikan pelajaran dan membantu siswa dalam belajar.

2) Menarik perhatian anak sehinga terdorong untuk lebih giat belajar.

3) Dapat membantu daya ingat siswa (retensi)

4) Dapat disimpulkan dan digunakan lagi apabila diperlukan pada saat yang lain.

(Sudirman et-al $1991: 220)$

Atas dasar uraian tersebut diatas, hendaknya guru mau mempertimbangkan penggunaan media gambar seri didalam pelaksanaan proses belajar mengajar terutama dalam pengajaran menulis karangan. Karena dengan gambar dapat merangsang imajinasi seorang siswa supaya suka bercerita tentang gambar yang dilihatnya sehingga selanjutnya diharapkan siswa tersebut dapat mampu menulis karangan sesuai dengan tema, ide, pengalaman dan kejadianya.

\section{b. Kajian Pustaka}

Menurut Laporan Penelitian Tindakan Kelas mata pelajaran Bahasa Indonesia kompetensi dasar menyusun paragraf berdasarkan bahan yang tersedia dengan memperhatikan penggunaan ejaan, yang dibuat oleh Nurhayati, Guru SD Negeri 1 Magelung, menyebutkan bahwa : Tujuan utama pembelajaran Bahasa Indonesia adalah meningkatkan keterampilan siswa dalam Bahasa Indonesia, pengetahuan bahasa diajarkan untuk menunjukan siswa terampil berbahasa yakni terampil menyimak, berbicara, membaca dan menulis.

Keterampilan berbahasa hanya bisa dikuasai dengan latihan yang terus menerus dan sistematis yakni harus sering berlatih menyimak, berbicara, membaca, dan menulis. Mata pelajaran Bahasa Indonesia adalah program untuk mengembangkan pengetahuan, keterampilan berbahasa, dan sikap positif terhadap bahasa.

\section{c. Kerangka Berpikir}

Dalam kegiatan belajar mengajar di kelas III semester 1 tahun pelajaran 2013 / 2014 SDN Jatipurwo Kecamatan Rowosari Kabupaten Kendal pada mata pelajaran Bahasa Indonesia Kompetensi Dasar menyusun paragraf berasarkan bahan yang tersedia dengan memperhatikan penggunaan ejaan, secara klasikal hasil belajar siswa masih rendah, hal ini disebabkan oleh beberapa faktor salah satunya pemilihan media yang kurang tepat.

Pembelajaran menggunakan media gambar seri dapat membantu siswa dalam keterampilan mengarang. Dengan melihat gambar, siswa dapat menarik isi kesimpulan dari gambar tersebut, kemudian dapat menguraikan dalam bentuk tulisan.

Cerita gambar seri adalah cara atau daya upaya dalam menyusun atau menulis suatu tulisan atau karangan dengan menerjemahkan isi pesan visual (gambar seri) ke dalam bentuk tulisan.

Karena dengan gambar dapat merangsang imajinasi seorang siswa supaya suka bercerita tentang gambar yang dilihatnya sehingga selanjutnya diharapkan siswa tersebut dapat mampu menulis karangan sesuai dengan tema, ide, pengalaman dan kejadiannya, sehingga meningkatkan hasil belajar siswa.

\section{d. Rencana Tindakan}

\section{Waktu Penelitian dan Lama Tindakan}

Dengan beberapa pertimbangan dan alasan penulis menentukan menggunakan waktu penelitian selama 3 bulan, mulai dari perencanaan sampai penulisan Laporan hasil penelitian tersebut. 


\section{Prosedur Penelitian}

Adapun rencana penelitian mengacu pada rancangan penelitian yang dilakukan oleh langkah- langkah penelitian sebagai berikut :

\section{Perencanaan}

Tahap perencanan meliputi pembuatan Rencana Pembelajaran lengkap dengan menetapkan tujuan perbaikan nyiapkan media pembelajaran dan menyusun langkah-langkah yang akan dilakukan dalam penelitian. Kemudian membangun kolaborasi dengan teman sejawat dan dosen PTK agar dapat lebih mencermati masalah-masalah yang dihadapi.

\section{Pelaksanaan Tindakan}

Pelaksaaan tindakan yang dilaksanakan dalam pembelajaran adalah kinerja guru dalam melaksanakan atau menerapkan media Gambar Seri dan aktivitas siswa selama dilaksanakan atau diterapkan Media Gambar Seri, Guru memberikan mata pelajaran tentang mengarang dengan menggunakan media gambar seri.

Kegiatan Belajar Mengajar berlangsung dengan tahapan biasa, seperti pada rencana pembelajaran, yaitu Kegiatan awal (apersepsi), Kegiatan inti, dan Kegiatan penutup.

\section{Observasi}

Selama proses KBM guru dan tim PTK mengumpulkan data tentang respon siswa dan apa saja yang penting terkait dengan penelitian. Jadi, kegiatan observasi mulai dilakukan pada waktu penelitian atau pada waktu pelaksanaan tindakan, dan setelah pelaksanaan tindakan. Kegiatan observasi meliputi pengumpulan data dan menganalisis data yang terkumpul tersebut bersama dengan tim PTK lainnya.

\section{Evaluasi}

Setelah data berhasil dikumpulkan oleh pelaksana PTK bersama tim, lanhkah selanjutnya yaitu mengevaluasi atau menilai apakah pelaksanaan pembelajaran telah sesuai dengan yang sudah direncanakan. Diskusi dengan teman sejawat atau tim untuk membahas data yang dikumpulkan.

\section{Refleksi}

Setelah mengobsevasi dan menganalisis data yang terkumpul, selanjutnya guru melakukan refleksi, dengan merenungkan mengapa ada usaha perbaikan yang tersebut. Melalui refleksi ini guru dapat mengetahui usaha yang sudah tercapai, usaha yang belum tercapai, dan apalagi yang harus diperbaiki dalam pembelajaran berikutnya atau pada siklus berikutnya.

Semua langkah dalam prosedur PTK ini dilakukan secara berulang-ulang (siklis). Refleksi pada siklus pertama di atas akan menjadi bahan permasalahan pada tahap perencanaan siklus kedua, dan begitu seterusnya.

\section{e. Data dan teknik pengumpulan data}

\section{Jenis data :}

\section{a. Data kualitatif}

Adalah analisis data diperoleh dari hasil observasi oleh pengamat yaitu mengenai aktivitas guru dan siswa dalam pembelajaran, juga mengenai motivasi siswa selama pembelajaran.

Data kualitatif dipaparkan dalam bentuk kalimat menurut kriteria untuk memperoleh kesimpulan.

\section{b. Data kuantitatif}

Adalah data yang diperoleh dari hasil belajar yang berupa angka-angka setelah siswa mendapatkan proses pembelajaran. Biasanya guru dalam memberikan penilaian data ini berupa angka-angka dengan skor yang telah dibuat.

\section{Teknik Pengumpulan Data}

Untuk mengumpulkan data-data selama perbaikan penelitian, peneliti menggunakan instrumen sebagai berikut:

\section{Lembar Observasi}

Secara sederhana, observasi berarti pengamatan dengan tujuan tertentu, yaitu untuk mengumpulkan data-data hasil perbaikan. Observasi dalam penelitian tindakan kelas dilakukan terhadap guru sebagai peneliti oleh supervisor 2, dan pengamatan (observasi) terhadap siswa sebagai subyek penelitian. 
Lembar observasi terhadap guru sebagai peneliti adalah jurnal yang telah disediakan. Lembar obsevasi untuk siswa sebagai subyek perbaikan penelitian adalah observasi aktivitas siswa selama proses pembelajaran.

2. Lembar tes / soal-soal tes

Untuk mengetahui hasil perbaikan pembelajaran, data-data dikumpulkan melalui hasil tes pembelajaran. Tes pembelajaran berupa soal-soal tes yang disusun dalam RPP (Rencana Perbaikan Pembelajaran) setiap siklus. Hasil tes pembelajaran dimasukkan ke dalam suatu tabel, kemudian dideskripsikan sehingga diketahui peningkatan perbaikan pembelajaran setiap siklusnya.

\section{d. Analisis data dan kriteria keberhasilan}

\section{Analisis data}

Dalam melakukan penelitian ini, peneliti menggunakan metode analisis deskriptif komparatif yang menjadikan peningkatan hasil belajar Bahasa Indonesia kompetensi dasar menyusun paragraf berdasarkan bahan yang tersedia dengan memperhatikan penggunaan ejaan. Data yang telah diperoleh akan diolah dengan teknik analisis deskriptif dan komparatif, artinya data dideskripsikan dengan cara membandingkan hasil setiap siklusnya. Peneliti membandingkan hasil sebelum penelitian dengan hasil pada akhir setiap siklus (Suwandi, 2008:70). Hasil analisis tersebut dijadikan dasar dalam penyusunan perencanaan tindakan untuk tahap berikutnya.

Selanjutnya hasil analisis kuantitatif dikonsultasikan pada pedoman konversi. Dalam penelitian ini digunakan pedoman konversi nilai absolut skala lima sebagai berikut :

\begin{tabular}{|l|l|}
\hline Interval & Kategori \\
\hline $91-100$ & Baik Sekali \\
\hline $81-90$ & Baik \\
\hline $71-80$ & Cukup \\
\hline $61-70$ & Kurang \\
\hline$\leq 60$ & Sangat kurang \\
\hline Jumlah & \\
\hline
\end{tabular}

Table 3.6 :Pedoman Konversi Nilai Absolute Skala Lima

Kriteria yang digunakan untuk mengukur keberhasilan dan kegagalan pembelajaran dapat dicermati melalui evaluasi kegiatan dalam bentuk nilai. adapun indicator kerja untuk mengukur prestasi atau keberhasilan belajar siswa adalah hasil belajar siswa dalam pembelajaran yang dinyatakan berhasil apabila $\geq 80 \%$ dari jumlah keseluruhan siswa dalam kelas telah mencapai ketuntasan individual.

\section{Kriteria Keberhasilan}

Kriteria yang digunakan untuk memajukan hasil belajar siswa adalah tingkat pemahaman siswa terhadap materi atau bahan ajar. Dengan kriteria tersebut siswa dinyatakan tuntas belajar jika telah mencapai tingkat pemahaman materi sesuai dengan Kriteria Ketuntasan Minimal yang telah ditentukan oleh sekolah yaitu 68 ke atas.

Untuk mengukur peningkatan pemahaman siswa terhadap pembelajaran adalah keterlibatan siswa secara aktif dalam proses pembelajaran, dan penemuan informasi. Jika siswa mampu member respon positif terhadap penjelasan dan pertanyaan yang diajukan oleh guru, aktif mencari dan menemukan informasi, aktif belajar dan bekerja kelompok, dan aktif mengkomunikasikan hasil kerja kelompok.

Kriteria untuk mengukur tingkat keberhasilan proses perbaikan pembelajaran adalah sebagai berikut :

a. Proses perbaikan pembelajaran Mata pelajaran Bahasa Indonesia kompetensi dasar menyusun paragraf berdasarkan bahan yang tersedia dengan memperhatikan penggunaan ejaan, dinyatakan berhasil jika $80 \%$ dari keseluruhan jumlah siswa tuntas belajar.

b. Siswa dinyatakan berhasil jika nilai rata-rata Bahasa Indonesia kompetensi dasar menyusun paragraf berdasarkan bahan yang tersedia dengan memperhatikan penggunaan ejaan keseluruhan siswa mencapai 80. 


\section{RUJUKAN}

Suriamiharja, Agus, dkk. 1997. Petunjuk Praktis Menulis. Jakarta : Depdikbud.

Sabarti, Akhadiah, 1997. Menulis. Jakarta : Depdikbud.

The Liang Gie 1992. Pengantar Dunia Karang Mengarang. Yogyakarta : Liberty

Tarigan, Djago. 1996. Membina Keterampilan Menulis Paragraf dan Pengembangannya. Bandung : Angkasa.

Wardani, IGAK, Kuswoyo Wihardi. 2009. Penelitian Tindakan Kelas. Jakarta : Pusat Penerbitan Universitas Terbuka.

Nasution. 2006. Asas-asas Kurikulum. Jakarta : Bumi Aksara. 